\title{
AMAZONANAS
}

DOI: https://doi.org/10.34069/RA/2021.7.05

Volumen 4, Número 7/enero-junio 2021

\section{Reconceptualising Self-leadership and Management Style within the Organization}

\section{Reconceptualizar el autoliderazgo y el estilo de gestión dentro de la organización}

Recibido: 28 de enero de $2021 \quad$ Aceptado: 23 de abril de 2021

Autores:

Fakhr e Alam Afridi ${ }^{15}$

\begin{abstract}
Urge of self-leadership has become ubiquitous. Self-leadership strategies has emerged to help individual, of which, when, effectively practiced, can lead to the path of rewarding performance and self-motivation. This study discusses the importance of management style introduced within the organisation and its ability to demonstrate effective self-leadership with the aim to organization objective achievement by taking the motivation of individual's into consideration as an important factor, which could be beneficial to the organization to gaining a strong position in this modern competitive business world.
\end{abstract}

Key words: Self leadership; performance; reward; motivation.

\section{Resumen}

La necesidad de auto-liderazgo se ha vuelto omnipresente. Han surgido estrategias de autoliderazgo para ayudar al individuo, las cuales, cuando se practican eficazmente, pueden conducir al camino del desempeño gratificante y la automotivación. Este estudio discute la importancia del estilo de gestión introducido dentro de la organización y su capacidad para demostrar un autoliderazgo efectivo con el objetivo de lograr el objetivo de la organización al tomar en consideración la motivación de los individuos como un factor importante, que podría ser beneficioso para la organización para ganar una posición sólida en este mundo empresarial competitivo moderno.

Palabras clave: Autoliderazgo; actuación; recompensa; motivación.

\section{Introduction}

Leadership is one of the most cherished and explored topics in scholarly circles (Gerpott, Fasbender, \& Burmeister, 2020). In the past decades, not only the number of leadership theories grown significantly but also the perspective of leadership itself varies as well. The concept of leadership is back date to "The Republic" documented by Plato's 400 B.C. and plenty of books, documentaries, studies, and movies exists, which describe leadership and a good leader. For example see "People Princess" Princess Diana. However, there is still uncovered areas about the concept.

However, it is important to explain that for an organization to survive nowadays in this competitive world of productivity, efficiency and efficacy (Larson \& DeChurch, 2020), it has to

\footnotetext{
${ }^{15}$ Ph.D. Scholar Islamia College Peshawar, Pakistan. ORCID: https://orcid.org/0000-0001-9776-5074
} 


\section{AMAZđ̛́NAS}

build a specific leadership (Göksoy, 2015), that is able to demonstrate intelligence, in all its aspects within the organisation to persuade the others, and introduce the management appropriate tend always consideration of motivation the staff (Larson \& DeChurch, 2020) with the objective of ensuring that they feel happy with their job to the evolution of organization (Ganta \& Manukonda, 2014).

However, from the explanations above one critical component missing is the fact that in a formal organizational setting leadership does not start. It has to be first emerge and mature internally, before expand into a process of influencing others to achieve organizational common goals. Peter Drucker a famous management theorist, and supporter of perspective of leadership as a personal relationship, emphasized frequently we should solidify our personal relationship by strengthen our inner-connection regularly with our sense of purpose (Drucker, 2005). Then it would be instrumental in knowing our weakness and strength, the way we could approach to others, make learn, choices, contribute, and values we held (Gilley, Dixon, \& Gilley, 2008).

This study discuss the importance of management style introduced within the organisation and it's the ability, to demonstrate effective self-leadership (Gilley et al., 2008), with the aim to organization objective achievement by taking the motivation of individual's into consideration as an important factor, which could be beneficial to the organization to gaining a strong position in this modern competitive business world (Liu, Lepak, Takeuchi, \& Sims Jr, 2003).

To this end, this study build on two specific statements that relate to management style and self-leadership within the organization.

Statement 1: The key to adopting the correct management style and demonstrating effective selfleadership lies in the understanding of the contingency approach.

Statement 2: The key to understanding the process of motivation lies in the meaning of and the relationship between, needs, drives and incentives.

\section{Methodology}

In accordance with the study objectives, we first discuss and review available literature on statement 1; "The key to adopting the correct management style and demonstrating effective leadership lies in the understanding of the contingency approach".

Next, we turn our attention to the statement 2; "The key to understanding the process of motivation lies in the meaning of and the relationship between, needs, drives and incentives".

\section{Statement 1}

"The key to adopting the correct management style and demonstrating effective leadership lies in the understanding of the contingency approach".

The contingency approach is based upon on the view that there is no best and universal form of organisation that all other bodies should follow because there are various number of considerations or on the hand factors that can influence the performance of organization (Pearce, Manz, \& Sims Jr, 2008). The leadership of each particular organization has to look at the existing situational factors and then try to apply the particular organisational and managerial variables which are most appropriate for the specific situation. In addition, the manager of the organisation should be focused on the organisation of the work in its totality and on the all elements interrelationships which affect organisational performance (Gilley et al., 2008). 


\section{AMAZÓNAS}

However, it is important to explain the importance of leadership and its efficiency within the organisation. Every business requires leadership to make the most of the skills its staff possess (Drucker, 2005).This is not just a matter of the dimensions of the organisation as no of people employee but to make sure that to make the most of their aptitudes and abilities. This requires a particular set of management skills, which means you have to be able to motivate the staff in all aspects (Lance Frazier, Johnson, Gavin, Gooty, \& Bradley Snow, 2010). In addition, in order to ensure that the orders given to the staff by the leader are efficacious the leader must not be separated from the activities of groups. However, there is a difference between leadership and management. This difference of behaviour impacts within the organisation, because leadership can be loosely defined as getting people to do things willingly whereas management is more commonly defined as getting things done by other people in order to achieve stated organisational objectives (Manz, 1983).

However, there is a close relationship between leadership and management, especially in work organisations. An example of this could be when the manager gives an order to the staff to serve the complementary drink to the customer without specifying how it is served. In this case the objective is to have the work done. Leadership would go on to specify how the drink would be served in terms of form efficiency. In addition leadership is just one of the many assets a successful manager must possess (Manz, 1992). The main aim of a manager is to maximize the output of the organization through administrative implementation (Bailey, Barber, \& Justice, 2018), to achieve these goals managers must undertake the following functions:

- To plan

- To organize

- To employee

- To direct.

- To control

Leadership is just one important component of the directing function (Politis, 2006). A manager cannot just be a leader he also needs formal authority to be effective. However, another responsibility of leadership is giving the right motivation to their staff and without fulfilling this responsibility (Manz \& Sims Jr, 1991), it is not possible to achieve the objectives of organization. All members of staff need motivation to do something. The leader cannot give an order without first identifying what the individual member of staff needs. This lack of attention to the individual staff needs will result in an unhappy team who do not have the motivation to carry out their work.

\section{Statement 2}

"The key to understanding the process of motivation lies in the meaning of and the relationship between, needs, drives and incentives".

Nowadays every employee needs motivation to do something such as: going to another country, studying a particular course etc.

"Some people get more done than others; some set goals while others drift along; some can't get started, others can't be stopped" "Managing people- motivation"

Employees are not machines where you can press buttons to make them work (Liu et al., 2003). The staff need motivation which in simple terms can be considered as the amount of effort an individual is willing to put into their work. A lack of motivation in any member of a team can have a negative effect reducing the group effectiveness and can also be de-motivating for others. In addition it is important to focus on the relationship among needs drives and incentives to 


\section{AMAZÖ́NAS}

understand motivation process that relates to each person (Fairholm \& Fairholm, 2000). However the definition of 'motivation' needs to be further discussed at a deeper level in terms of theory.

\section{Theoretical framework}

\section{Maslow}

Maslow's theory is built around on the human "needs". Maslow (an American psychologist) categorized five needs that one grows based on the lower needs and used a pyramid to illustrate.

\section{The Maslow pyramid}

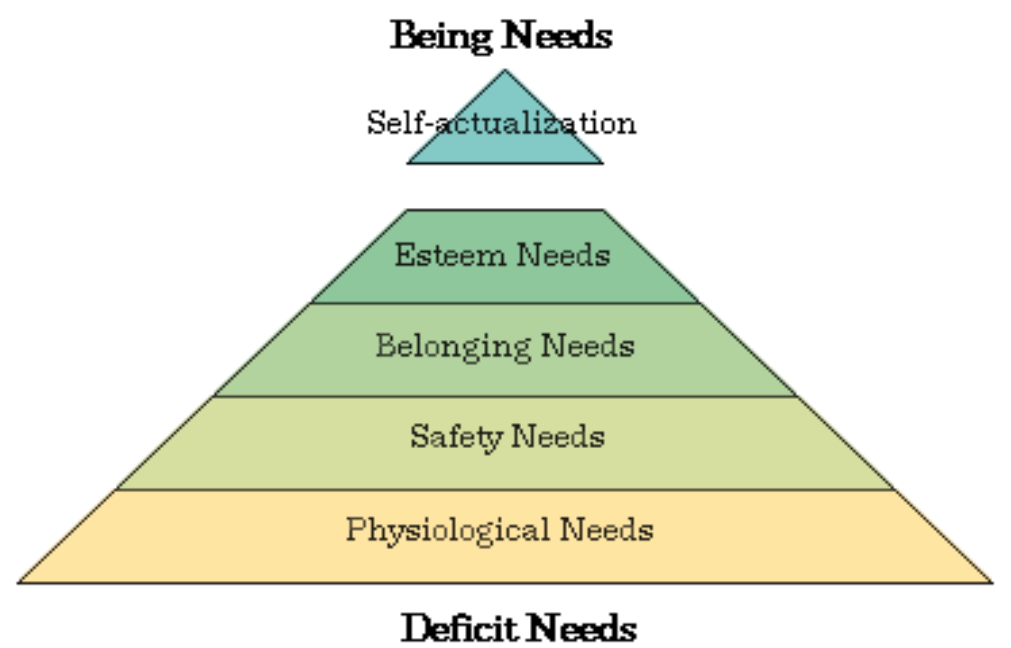

Figure 1. five needs that are incorporated in the Maslow pyramid.

This figure represents the five needs that are incorporated in the Maslow pyramid.

\section{"Brief explanation of hierarchal level of needs"}

1. Physiological Needs: This include air, food, warmth, sleep, activity and stimulation. These needs can be very important therefore if people are deprived of these over time, the person cannot live.

2. Safety Needs: include the needs to feel safe such as living in secured area away from potential threats. These needs are more focussed in children and premature therefore they have a greater need to feel safe.

3. Belonging Needs: consist the need to belong a social group. To feel part of some group e.g. "football team" and to be loved such as friends and family.

4. Esteem Needs: This include self-respect and respect from others. In other words, the opinion others have of us and the opinion we have of ourselves.

5. Self- actualization: This include realization of potentials and personal growth. This is the stage where people become fully functional, behave purely on their own volition and having a desired personality.

Maslow theory can be considered the most popular theory and has had a big impact on management approaches on management and the design of organisations to meet individual needs. It can be applied from the lowest to the highest level of organisation despite the fact that both levels have different needs (Blynova et al., 2020). For example a manager has different needs than a waiter. 


\section{AMAZONANAS}

However, this theory cannot addressed all individual sources of motivation. Leaders can motivate some employees but not all because not all people are driven by the same needs and incentives (Manz, 1992). It is important to understand that needs and incentives are different according to each employee. The leader must be able to recognise the needs level at which the employee is operating to motivate an employee, and use those needs as levels of motivation. It is worthy to mention that with this kind of approach the leader can motivate the whole team because he or she can give the appropriate weighted to the importance of the needs of each employee.

In addition after lots of investigations we can conclude there is not one best theory that managers can use to motivate staff therefore all employees have different needs, drives and incentives (Pearce \& Manz, 2011). The most important knowledge theories (Maslow, theory $\mathrm{x}$ theory y, Herzberg, McClelland's) can serve to give managers or leaders an idea of how to motivate the staff, taking in consideration that each one has different ideas from the other. For example for some employees money can be the biggest source of motivation but for other employees responsibility can be more important than money. These are factors that the leader has to examine the employees closely for in order to know their individual needs, drives and incentives.

However, there is one theory which could be more appropriate compared to the others and which can be useful to enable new managers or leaders to understand the process of motivation at work. The result of the successful application of this theory would be that all employees feel satisfied and the title of this theory is 'the motivator hygiene theory' which was developed by Frederick Herzberg.

According to "Herzberg" (motivation and hygiene theory) when people have job satisfaction motivation will occurs. By increasing opportunities for job satisfaction can be improved:

\section{Motivating Factors}

- Achievement.

- Work itself.

- Recognition.

- Responsibility.

- Personal Growth

- Advancement.

This group of six factors are the types of motivation that the employees want. In addition it is important to show which factors can cause dissatisfaction in organisations.

- Hygiene factors

- Work conditions

- Salary

- Relationship with Boss.

- Supervision.

- Relationship with peers.

- Company Policy.

According to Herzberg's theory these two levels of needs (motivation factor and hygiene factor) even if they operate in different ways are very important for job satisfaction. The employers will become dissatisfied if the lower needs are inadequate, however, as these needs are satisfied trying to motivate staff by just adding more hygiene factors such as wages and working 


\section{AMAZÓNAS}

hours is an inefficient and short term solution. For example an appropriate way would be to appeal to their higher level needs by giving them more responsibility or giving them greater opportunity for advancement. In this way the individual goals are satisfied in that the different needs, drives and incentives of each employee are met. As a result the organisation has their targets achieved.

Herzberg's theory supports the argument that people want more than just a pay packet out of their employment. They want to achieve and be recognised for the work that they do. However, to him the elements that cause satisfaction and dissatisfaction are different. The team leader has to prioritize that every single person needs to think that they are working with the best people to feel proud to be part of the team (Manz, 1992). By getting people into this state of mind a leader will instil high group morale; the people will work harder and as result will achieve more (Manz \& Sims, 2001).

Modern businesses have the objective of becoming more competitive in relation to other companies in their efficiency and improvements of the product or the service provided to the customer. It is important for potential leaders or managers to remember that there is no one best style that can be introduced in the organization with the objective of improving the business (Ganta \& Manukonda, 2014).

However, the new leader or manager of any given organisation has the important role of ensuring that there is a good atmosphere in the particular department that will be administrated by him/her (Manz \& Gioia, 1983). This means identifying which would be the correct technique to improve the service and then introducing an appropriate management style that could be useful in the specific department. To conclude it is clearly beneficial to see the motivation of employees as an important asset of the company because it is them who can make the business survive (Manz, Pearce, Mott, Henson, \& Sims Jr, 2013). Attention should be given to each individual employee to see which their needs, drives are and incentives (Manz, 1992). These are important factors for any contemporary business to become profitable and competitive in this world in relation to the others companies.

\section{Discussion}

It has become abundantly clear in last decade that today's workforce is looking different qualities and skills in its leaders, not only through shift in corporate level, but also shifts in and topics or areas that researchers focus on these days and being thought in business schools. On the other hand modern organizations face unprecedented challenges in today's fast-paced, high-tech based competitive environments (Voronkova, Nikitenko, Teslenko, \& Bilohur, 2020). As organizational members at all levels are being encouraged to take greater responsibility for their own work behaviours and job tasks (Bijlsma-Frankema \& Koopman, 2003).

However, skills one learn at school/college may not be enough at the time of employment. The concept of self-leadership have impressive potential for applicants in today's dynamic competitive environment. It is a process through which people influence themselves to achieve the self-direction and self- motivation necessary to perform in workplace. This can be achieved through the combined utilization of self-leadership's three components: behaviour-focused strategies, constructive thought pattern strategies and natural reward strategies.

Self-leadership in this modern business world, is an uplifting concept, which, when, effectively practiced, can lead to the path of rewarding performance. Which both are powerful driving motive towards performing effectively. Some researchers perceived it as a complex process mainly focused on influencing others. 


\section{AMAZÓNAS}

\section{Conclusion}

As was explained in the statements above leadership is one of the most important factors within any organisation. Even if one have not had the opportunity to experience leadership. Reader can have through study understood that there is no one best form of leadership. However we have been able to identify that having a wide understanding of the possible types of motivation is more useful than adopting a single approach to management. In our opinion the most adaptable theory for modern day use is Herzberg because it has greater relevance to people's needs for both stimulation and the need for employees to have a positive relationship with the company they work for.

In personal terms we think the range of skills one have would be useful and transferable to the organisation. One greatest proven skills are in working effectively within a team, communicating efficiently, and manipulating information technology to store and handle information (Manz \& Sims, 2001). In addition one should be flexible enough and adaptable to new situations that could be useful to the organisation; the greatest proof of skill was adapting to this Country and new situations that it was brought and, acquiring a new quality such as a new language.

In addition we believe one should be determinate, enthusiastic and sensitive; and these three values are useful for the organisation because important decisions can be with determination which influence others with honesty and enthusiasm 36 . However, according to the personal inventory as a sociable person, organised, hardworking responsible to others avoiding conflict (Liu et al., 2003) and good listener. However, we noticed the weakness points within oneself are that of lack creativity if one do not feel comfortable with a situation one get easily bored, and can be extremely demanding to oneself.

In terms of leadership style we suggest not adopt a dogmatic or dictatorial style of management (Marques, 2014)but would prefer to work closely with in team and provide clear explanations of what we want from them and in this way identify clear goals and targets that they can then improve upon. We also feel that this contact would enable individual to better assist staff (Mastrangelo, Eddy, \& Lorenzet, 2004) in improving techniques in their own area of expertise, such as methods for storing and handling data and other I.T issues. Based on the comparison made between leadership and management themes, current studies is worth further to investigate. Empirical studies will be needed to verify the assumptions.

\section{References}

Bailey, S. F., Barber, L. K., \& Justice, L. M. (2018). Is self-leadership just self-regulation? Exploring construct validity with HEXACO and self-regulatory traits. Current Psychology, 37(1), 149-161.

Bijlsma-Frankema, K., \& Koopman, P. (2003). Trust within organisations: introduction to a special issue. Personnel Review, 32(5), 543-555.

Blynova, O., Popovych, I., Semenova, N., Kashyrina, Y., Ursulenko, O., \& Kononenko, O. (2020). Personality Factors of Choosing Adaptation Strategies in a Different Cultural Environment by Labor Migrants from Ukraine. Amazonia Investiga, 9(32), 45-54.

Drucker, P. F. (2005). Managing oneself. Harvard Business Review, 83(1), 100-109.

Fairholm, M. R., \& Fairholm, G. (2000). Leadership amid the constraints of trust. Leadership \& Organization Development Journal. 21(2):102-109

Ganta, V. C., \& Manukonda, J. K. (2014). Leadership during change and uncertainty in organizations. International Journal of Organizational Behaviour \& Management Perspectives, 3(3), 1183. 


\section{AMAZÚNAS}

Gerpott, F. H., Fasbender, U., \& Burmeister, A. (2020). Respectful leadership and followers' knowledge sharing: A social mindfulness lens. Human Relations, 73(6), 789-810.

Gilley, A., Dixon, P., \& Gilley, J. W. (2008). Characteristics of leadership effectiveness: Implementing change and driving innovation in organizations. Human resource development quarterly, 19(2), 153-169.

Göksoy, S. (2015). Distributed Leadership in Educational Institutions. Journal of Education and Training Studies, 3(4). doi:10.11114/jets.v3i4.851

Lance Frazier, M., Johnson, P. D., Gavin, M., Gooty, J., \& Bradley Snow, D. (2010). Organizational justice, trustworthiness, and trust: A multifoci examination. Group \& Organization Management, 35(1), 39-76.

Larson, L., \& DeChurch, L. (2020). Leading Teams in the Digital Age: Four Perspectives on Technology and What They Mean for Leading Teams. Leadersh Q, 31(1). doi: 10.1016/j.leaqua.2019.101377

Liu, W., Lepak, D. P., Takeuchi, R., \& Sims Jr, H. P. (2003). Matching leadership styles with employment modes: Strategic human resource management perspective. Human resource management review, 13(1), 127-152.

Manz, C. C. (1983). Improving performance through self-leadership. National productivity review, 2(3), 288-297.

Manz, C. C. (1992). Self-leading work teams: Moving beyond self-management myths. Human Relations, 45(11), 1119-1140.

Manz, C. C., \& Gioia, D. A. (1983). The interrelationship of power and control. Human Relations, 36(5), 459-475.

Manz, C. C., Pearce, C. L., Mott, J. W., Henson, Z., \& Sims Jr, H. P. (2013). Don't take the lead... share the lead. Organizational Dynamics, 42(1), 54-60.

Manz, C. C., \& Sims, H. P. (2001). The new superleadership: Leading others to lead themselves. Berrett-Koehler Publishers.

Manz, C. C., \& Sims Jr, H. P. (1991). Superleadership: Beyond the myth of heroic leadership. Organizational Dynamics, 19(4), 18-35.

Marques, J. (2014). An Expanded View of Leadership Leadership and Mindful Behavior (pp. 117): Springer.

Mastrangelo, A., Eddy, E. R., \& Lorenzet, S. J. (2004). The importance of personal and professional leadership. Leadership \& Organization Development Journal. 25(5):435-451

Pearce, C. L., \& Manz, C. C. (2011). Leadership centrality and corporate social ir-responsibility (CSIR): The potential ameliorating effects of self and shared leadership on CSIR. Journal of Business Ethics, 102(4), 563.

Pearce, C. L., Manz, C. C., \& Sims Jr, H. P. (2008). The roles of vertical and shared leadership in the enactment of executive corruption: Implications for research and practice. The Leadership Quarterly, 19(3), 353-359.

Politis, J. D. (2006). The Impact of Leadership and Power on Perceptions of Creativity in the Workplace. Paper presented at the 2nd European Conference on IS Management, Leadership and Governance.

Voronkova, V. H., Nikitenko, V. A., Teslenko, T. V., \& Bilohur, V. E. (2020). Impact of the worldwide trends on the development of the digital economy. Amazonia Investiga, 9(32), 81-90. https://amazoniainvestiga.info/index.php/amazonia/article/view/1478 